Western North American Naturalist 70(3), (C) 2010, pp. 413-414

\title{
CLARK’S NUTCRACKERS HARVEST SUGAR PINE SEEDS FROM CONES
}

\author{
Michael P. Murray ${ }^{1}$ and Diana F. Tomback ${ }^{2}$
}

\begin{abstract}
This is the first report of Clark's Nutcrackers (Nucifraga columbiana) harvesting seeds from the cones of sugar pine (Pinus lambertiana), based on observations over several years in Crater Lake National Park, Oregon. The harvesting period in late September corresponded to peak cone-opening dates. Nutcrackers placed harvested seeds in their throat pouches, a behavior associated with seed caching.
\end{abstract}

Key words: Clark's Nutcracker, Nucifraga columbiana, seed dispersal, sugar pine, Pinus lambertiana.

Sugar pine (Pinus lambertiana) is the largest member of the genus Pinus. It is known to attain heights over $70 \mathrm{~m}$, live as long as 600 years, and grow the longest-known cones in North America (up to $66 \mathrm{~cm}$ ) (Harlow et. al 1979, Kinloch and Scheuner 1990). Sugar pine is a common tree of the Sierra Nevada, Cascade, and coastal ranges of California and Oregon. Its seeds are among the largest of the pines (average of approximately $0.216 \mathrm{~g}$; Tomback and Linhart 1990).

We report anecdotal observations of Clark's Nutcrackers (Nucifraga columbiana) harvesting seeds from sugar pine cones in Crater Lake National Park, Oregon (elevation 1400 m, UTM Zone 10, 575472 E, 4736830 N, NAD 27). Most sugar pine cones open rapidly in late September in this area. All of our observations of nutcracker seed harvest took place during this time period.

During the early afternoon of 30 September 2004, a single Clark's Nutcracker landed on top of a cluster of 2 cones hanging from a large ( 2-meter-dbh) sugar pine tree. The bird swung forward to an upside-down (inverted) position and probed with its beak between several cone scales in rapid succession before flying to a nearby tree. Within about a minute, the bird returned, repeated this behavior, and then flew off again. Shortly thereafter, it returned for a final visit, probed the cone, and departed the vicinity. No nutcrackers were observed during October. On 27 September 2005, 2 nutcrackers were observed foraging in a similar manner for about 11 minutes.
In the early afternoon of 22 September 2006 , several nutcrackers comprising a small flock, or family group, foraged within a single tree. As observed in 2004 and 2005, all nutcrackers perched on the top of cones and foraged while inverted, removing seeds from cones one at a time. Each bird remained on a cone for about 2 minutes before flying to a branch in the same or nearby tree. While perched, each bird rubbed its beak against a branch until the seed wing was detached from the seed and fell to the ground. Then the bird abruptly jerked its beak upward, apparently dropping the seed into its throat pouch (e.g., Tomback 1978). By counting each seed wing removed, we estimated that individual birds collected between 2 and 31 seeds per cone or cone cluster $(\bar{x}=9.5$ seeds). The nutcracker that collected 31 seeds from a single cone cluster was able to remove all seed wings and pouch the seeds while inverted on the cone cluster, unlike the other nutcrackers.

We are unaware of any published accounts of Clark's Nutcrackers harvesting sugar pine seeds from cones. Clark's Nutcrackers are known to harvest and cache (scatter-hoard) the seeds of a number of pines and serve as important seed dispersers for several large-seeded species (Tomback and Linhart 1990, Tomback 1998). Filling the throat pouch during seed harvest is a nutcracker behavior typically associated with seed caching in late summer and fall. Vander Wall (2008) noted that nutcrackers "ignored" sugar pine cones in his study area. Further information on these interactions, including the timing and duration of seed harvest, seed caching

\footnotetext{
${ }^{1}$ Ministry of Forests and Range, Kootenay Lake Forestry Centre, 1907 Ridgewood Rd., Nelson, British Columbia VlL 6K1, Canada.

2Department of Integrative Biology, University of Colorado Denver, PO Box 173364, Denver, CO 80217-3364.
} 
behavior, and relationship between caches and tree regeneration, would contribute to our ecological knowledge of these species.

\section{Literature Cited}

Harlow, W.M., E.S. Harrar, and F.M. White. 1979 Textbook of dendrology. McGraw-Hill, New York, NY.

Kinloch, B.B., AND W.H. Scheuner. 1990. Sugar pine (Pinus lambertiana). In R.P. Burns and B.H. Honkala, editors, Silvics of North America. Volume 1, Conifers. Agriculture Handbook 654, USDA Forest Service, Washington, DC. Available from: http://na.fs.fed.us/ pubs/silvics_manual/Volume_1/pinus/lambertiana.htm
Tомваск, D.F. 1978. Foraging strategies of Clark's Nutcracker. Living Bird 16:123-161.

1998. The Clark's Nutcracker (Nucifraga columbiana). In A. Poole and F. Gill, editors, The birds of North America, no. 331. The Birds of North America, Inc., Washington, DC.

Tomback, D.F., and Y.B. Linhart. 1990. The evolution of bird-dispersed pines. Evolutionary Ecology 4:185-219.

VANDER WALL, S.B. 2008. On the relative contributions of wind vs. animals to seed dispersal of four Sierra Nevada pines. Ecology 89:1837-1849.

Received 15 December 2009 Accepted 3 May 2010 